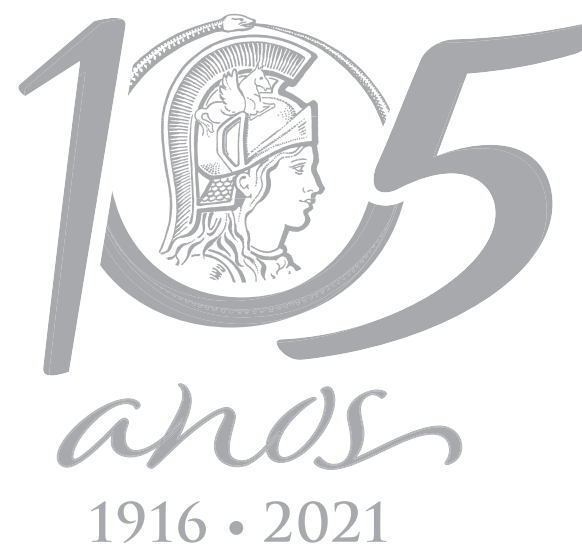

\title{
Psyllotoxus griseocinctus Thomson, 1868 (Coleoptera: Cerambycidae): a potential pest of roses in Brazil revealed by its lifecycle and niche modeling
}

\author{
DIEGO S. SOUZA, SILVANA LAMPERT, TATIANA A. SEPÚLVEDA, PRISCILA A. SANZ- \\ VEIGA \& MARCOANDRE SAVARIS
}

\begin{abstract}
We present the first formal record of the twig-girdler Psyllotoxus griseocinctus Thomson, 1868 (Cerambycidae: Lamiinae: Onciderini) attacking the rose, Rosa sp. (Rosaceae) in Southern Brazil. We provide photographs of the damage P. griseocinctus causes to the plant, as well as morphological descriptions of the immature stages and molecular diagnostic tools to identify this species. Additionally, we provide a modelled map with the known and potential distribution of P. griseocinctus and new host records for three plant species: the common walnut tree, Juglans regia L. (Juglandaceae); the cambucá tree, Plinia edulis (Vell.) Sobral (Myrtaceae); and the cherry tree, Prunus cf. serrulata Lindl. (Rosaceae).
\end{abstract}

Key words: Crops, host plants, Lamiinae, longhorned beetles, Onciderini, twig-girdlers.

\section{INTRODUCTION}

Psyllotoxus Thomson, 1868 is a South American genus of twig-girdling longhorned beetles (Cerambycidae: Lamiinae: Onciderini) composed of four species: Psyllotoxus dalensi Nearns \& Tavakilian, 2012 and P. faurei Nearns \& Tavakilian, 2012, both only known from the Amazon region in French Guiana; and P. griseocinctus Thomson, 1868 and P. inexpectatus Martins \& Galileo, 1990, both distributed across the Atlantic Forest and Cerrado biomes in Brazil (Nearns \& Tavakilian 2012, Monné 2021). Among these species, P. griseocinctus is known as the most generalist onciderine species (Paro et al. 2011), being associated with a wide variety of plant species from families Fagaceae, Lauraceae, Myrtaceae and Rosaceae (Santos \& Rosado-Neto 1977, Monné 2021).
Psyllotoxus species are commonly referred to as twig-girdlers because their females cut/ circumcise the branches of living plants for oviposition (Zajciw 1974a). This destructive behavior, which seems to be exclusive in members of Onciderini (Souza et al. 2020), prevents the circulation of phloem across the plant and kills the cut branch (Wang 2017). Several twig-girdling species, including $P$. griseocinctus, have earned pest status for this behavior, because they compromise the plant development and may produce economic impact when using commercial crops as host plants (Oliveira \& Costa 2014).

Among the botanical species used by $P$. griseocinctus as host plants, over 10 species can be found as growing agricultural crops or carry some economic importance in Brazil, including both native and introduced species, especially from the families and Myrtaceae 
and Rosaceae (Monné 2021; see Table I). Economically important species of Rosaceae have been extensively reported as host plants for many cerambycids in different regions of the world (Wang 2017), including both fruit trees and wild roses (Sharifi et al. 1970). The genus Rosa L. includes about 200 described species widely distributed in the temperate and subtropical zones of the northern hemisphere (The Plant List 2013, Fougère-Danezan et al. 2015). Modern rose crops, however, comprise many different cultivars originated from hybridization between Asian, European, Mediterranean and Middle Eastern rose species (Hurst 1941, Martin et al. 2001, Martins et al. 2009). In Brazil, rose cultivation represents a market of 200 million dollars per year (Martins et al. 2009, Carvalho et al. 2013). Brazilian rose production is mostly destined to internal market of cut flowers and gardening use (Junqueira \& Peetz 2014, Júnior et al. 2015). However, roses are also cultivated to be used as raw material for the production of essential oils and pharmacological compounds (Cheng et al. 2016).

Although the damage that P. griseocinctus causes in some economically important plants is relatively recognized (Santos \& Moura 1979, Silva et al. 1968, Zajciw 1974a, Link et al. 1988),

Table I. Botanical species used by $P$. griseocinctus as host plants.

\begin{tabular}{|c|c|c|c|}
\hline Plant species & Common name & Plant family & Reference \\
\hline Quercus sp. & - & Fagaceae & Santos \& Rosado-Neto 1977 \\
\hline Persea pyrifolia Nees & - & Lauraceae & Paro et al. 2011 \\
\hline Campomanesia aurea Berg. & - & Myrtaceae & Link et al. 1988 \\
\hline Eucalyptus camaldulensis Dehnh & eucalyptus tree & Myrtaceae & Santos \& Moura 1979 \\
\hline Eucalyptus urophylla Blake. & eucalyptus tree & Myrtaceae & Santos \& Moura 1979 \\
\hline Eugenia pyriformis Cambess & uvaia tree & Myrtaceae & Paro et al. 2011 \\
\hline Eugenia uniflora L. & pitanga tree & Myrtaceae & Link et al. 1988, Paro et al. 2011 \\
\hline Myrcia edulis (Berg) Krug \& Urb. & - & Myrtaceae & Marinoni 1969 \\
\hline Myrcianthes pungens (Berg) D. Legrand & - & Myrtaceae & Link et al. 1988 \\
\hline Myrciaria baporeti Legrand & - & Myrtaceae & Link et al. 1988 \\
\hline Plinia cauliflora (Mart.) Kausel & jaboticaba tree & Myrtaceae & Silva et al. 1968 \\
\hline Psidium cattleianum Sabine & guava tree & Myrtaceae & Paro et al. 2011 \\
\hline Psidium guajava L. & guava tree & Myrtaceae & $\begin{array}{c}\text { Zikán \& Zikán 1944, Silva et al. } \\
\text { 1968, Paro et al. } 2011\end{array}$ \\
\hline Syzygium cumini (L.) Skeels & - & Myrtaceae & Paro et al. 2011 \\
\hline Syzygium malaccensis (L.) Merr. \& Perry & - & Myrtaceae & Silva et al. 1968 \\
\hline Malus sylvestris (L.) Miller & $\begin{array}{l}\text { European crab } \\
\text { apple tree }\end{array}$ & Rosaceae & Zajciw $1974 a$ \\
\hline Prunus domestica L. & peach tree & Rosaceae & Zajciw 1974a \\
\hline Prunus persica (L.) Batsch & peach tree & Rosaceae & Zajciw 1974a \\
\hline Pyrus communis L. & pear tree & Rosaceae & Zajciw 1974a \\
\hline
\end{tabular}


little is known about taxonomy and natural history of this species. Herein, we provide the first formal record of $P$. griseocinctus damaging roses (Rosa sp.) in the municipality of Colombo, Southern Brazil. Considering the potential for this species to become a pest not only for roses but for other economically important crops in Brazil, we provide morphological and molecular diagnostic tools for its identification, including biological aspects and illustrations of its developmental stages, and a modelled map with the potential distribution of the species. Additionally, three new host plant records of $P$. griseocinctus are provided.

\section{MATERIALS AND METHODS}

A rose plant with characteristic damage caused by twig-girdling beetles (Fig. 1a, indicated by white arrow) was collected in August 30, 2017, in a garden at the rural area in Colombo, Paraná, Brazil (2522'45.46"S, 4907'53.69"W; 908 m.a.s.l.). The collected plant, with several branches, was cut into smaller pieces $(25-30 \mathrm{~cm})$ and the larvae were reared to adulthood in a voile box $(30 \mathrm{~cm}$ x $40 \mathrm{~cm}$ ). The samples were weekly moistened until the emergence of adults. The behavioral aspects were described from observation of the female specimen that girdled the rose bush, which was collected with the plant, and the offsprings obtained from the rearing, including two larvae, one pupa and one adult female. The adult emerged specimen was identified using a key for Psyllotoxus provided by Nearns \& Tavakilian (2012) and the determination was confirmed by comparing the specimens with the photograph of the lectotype of $P$. griseocinctus available on Bezark (2020). All examined specimens, including larvae, pupa and adult, were deposited in the Entomological Collection 'Padre Jesus Santiago Moure', Department of
Zoology, Federal University of Paraná, Brazil (DZUP) under the following voucher numbers: DZUP 311244-311247.

The photographs of biological aspects of $P$. griseocinctus were made using a Nikon D7200 camera and the detailed photographs of larva and pupa were made using a Leica DFC 500 digital camera on a Leica MZ16 stereoscope and mounted using the software Leica LAS 3D Viewer and LAS Montage v.4.7. The terminology used for immature structures follows Švácha \& Lawrence (2014).

The map with the potential distribution of $P$. griseocinctus was estimated in DIVA GIS version 7.5.0 (Hijmans et al. 2004) using maximum entropy algorithm, as implemented in MaxEnt v.3.4.1 (Phillips et al. 2006), and the climate data was obtained from WorldClim version 2 (Fick \& Hijmans 2017). It is known that climatic factors are strongly correlated with seasonality, abundance and period of activity of the twig-girdling beetles (Paro et al. 2012). In order to identify which of the 19 WorldClim climatic variables should be used for the map estimation, we assessed the spatial correlation of the environmental variables by Pearson's correlation coefficient ( $r$ ) analysis using ENMTools 1.4.4 (Warren et al. 2010), maintaining a single variable for each correlated pair of layers with $r>0.75$ (Šmíd et al. 2017). Based on Pearson's correlation coefficients, the following variables were incorporated in the modeling: $\mathrm{BIO3}=$ Isothermality, $\mathrm{BIO4}=$ Temperature seasonality, $\mathrm{BIO5}=$ Max temperature of warmest month, $\mathrm{BIO7}=$ Temperature annual range, $\mathrm{BIO11}$ = Mean temperature of coldest quarter and $\mathrm{BIO12}=$ Annual precipitation .

Distribution data of the species were obtained from the labels of specimens deposited in the DZUP and the Museum of Zoology, University of São Paulo, São Paulo, Brazil (MZUSP), as well as from previous records 
from literature cited in Monné (2021). Records lacking coordinates were georeferenced using Google Earth (https://www.google.com/earth/). Models were generated in MaxEnt based on 34 occurrence points (see Supplementary Material - Table SI) using the following settings: maximum number of iterations $=5000$; replicates $=10$; replicated run type = cross-validate, output format = logistic. The average output was used for evaluating and visualize the model.

We extracted genomic DNA from both larva and adult of $P$. griseocinctus by a nondestructive method using DNeasy Blood and Tissue Kit (Qiagen), following the manufacturer's protocol. PCR amplification was performed to obtain a fragment of the mtDNA cytochrome c oxidase subunit 1 (cox1) using the universal primers LCO1490 and HCO2198 (Folmer et al. 1994) and the following cycle conditions: initial denaturation at $94{ }^{\circ} \mathrm{C}$ for 3 min followed by 40 cycles of denaturation at $94^{\circ} \mathrm{C}$ for $1 \mathrm{~min}$, annealing at $58{ }^{\circ} \mathrm{C}$ for $1 \mathrm{~min}$ and elongation at $72{ }^{\circ} \mathrm{C}$ for $2 \mathrm{~min}$, with a final elongation at $72{ }^{\circ} \mathrm{C}$ for $5 \mathrm{~min}$.

\section{RESULTS}

\section{Biological aspects of $P$. griseocinctus in rose}

It had been reported that the females of $P$. griseocinctus girdle the bark and part of the woody region of the plants before laying their eggs. In the case reported here, the girdling was made at the base of the main stem of the rose bush, which resulted in the sprouting of a lateral branch after the death of the main stem (Fig. 1a). The eggs were laid in the crack, partially in the woody area of the branch and under the bark (Fig. 1b, indicated by black arrow). Egg laying was performed along the main cut trunk and branches, and a single egg was laid on each oviposition site. After laying, the female covered the eggs with a resinous substance (Fig. 1c, indicated by orange arrow).

Approximately 30-34 days after laying the eggs, the first residues of larval excretion were observed inside the rearing voile box (Fig. 1d, indicated by yellow arrow). The larvae of $P$. griseocinctus are essentially xylophagous and develop inside the dead rose trunk and branches, opening galleries in the wood as they feed (Figs. 1e, f). Sometimes it was possible to find some small granules of larval excrement inside the trunk and branches galleries made by the larvae (Fig. 1e, indicated by green arrow). After approximately four months, the galleries formed by the larvae could be located by pressing the bark of the attacked trunk and branches, which became malleable. When opening these malleable areas, it was possible to find the larvae and note the damage they caused to the plant. The mature larvae used their own residues and wood shavings to form a camera inside the branches where they pupated (Fig. 1g, indicated by red arrow). The larvae of $P$. griseocinctus began to pupate inside the branch about four months after the plant collection (Figs. 1g, h) and the adult (Figs. 1d, i, j) emerged about a month after pupation, in January 14, 2018. Thus, the life cycle of $P$. griseocinctus in rose lasted approximately 135 days.

\section{Identification of the immature stages of $P$. griseocinctus}

The external morphology of larva and pupa of $P$. griseocinctus was described by Zajciw (1974b). Herein, we complement Zajciw's (1974a) description by providing practical diagnoses and new illustrations of the egg (Fig. 1b, indicated by black arrow), the third instar larva (Figs. 2a-f) and the pupa (Figs. 2g-i), highlighting the main morphological structures used for identification of the larva and pupa of this species. 

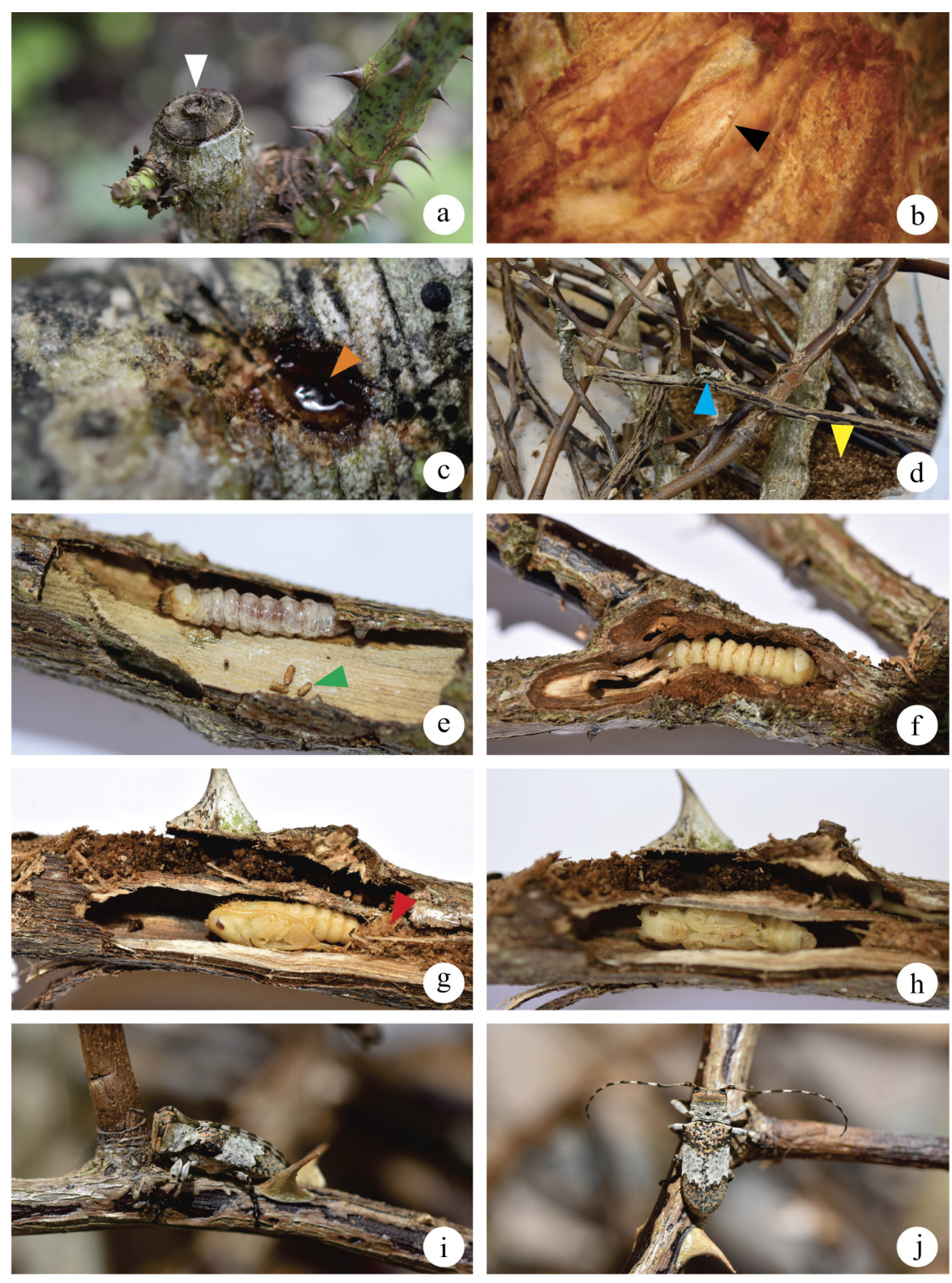

Figures 1. Biological aspects of Psyllotoxus griseocinctus in rose plant. a, rose branches with a characteristic damage caused by beetles. $b$, egg (indicated by black arrow). c, rose bush bark cut by females to lay eggs and resinous substance used to close the oviposition opening (indicated by orange arrow). d, larval excretion residues (indicated by yellow arrow) and emerged adult (indicated by blue arrow). e-f, larvae feeding on wood. g-h, pupae inside the branches. $\mathrm{i}-\mathrm{j}$, adults.
The egg (length $2.4 \mathrm{~mm}$ ) of $P$. griseocinctus is elongate, slightly flattened and pale yellow colored (Fig. 1b, indicated by black arrow). The larva is apodous (length 15.8-30 mm), predominantly whitish to pale yellow. The following traits are complementary to Zajciw's (1974a) description and can be used to diagnose the larva of P. griseocinctus (structures between parenthesis are indicated in Figs. 2a-f): head oblong in dorsal view; with a transverse row of longitudinal carinae (tlc) on the prefrontal region (prf), absent on the median frontal line $(m f l)$; lateral margins of epicranium (ecr) convergent; antennae (ant) very short, 2-segmented, positioned near mandibula base; clypeus $(c l)$ glabrous, about same length of labrum (lbr); labial and maxillary palps (Ip and mp) 3-segmented; mandibles ( $m d$ ) shiny dark brown; gula ( $\mathrm{gu}$ ) slightly tumescent; hypostomal line (hypl) clearly evident; pronotum ( $p n$ ) anteriorly sclerotized and hairy across alar lobe (al), posteriorly with a differentiated smooth and 

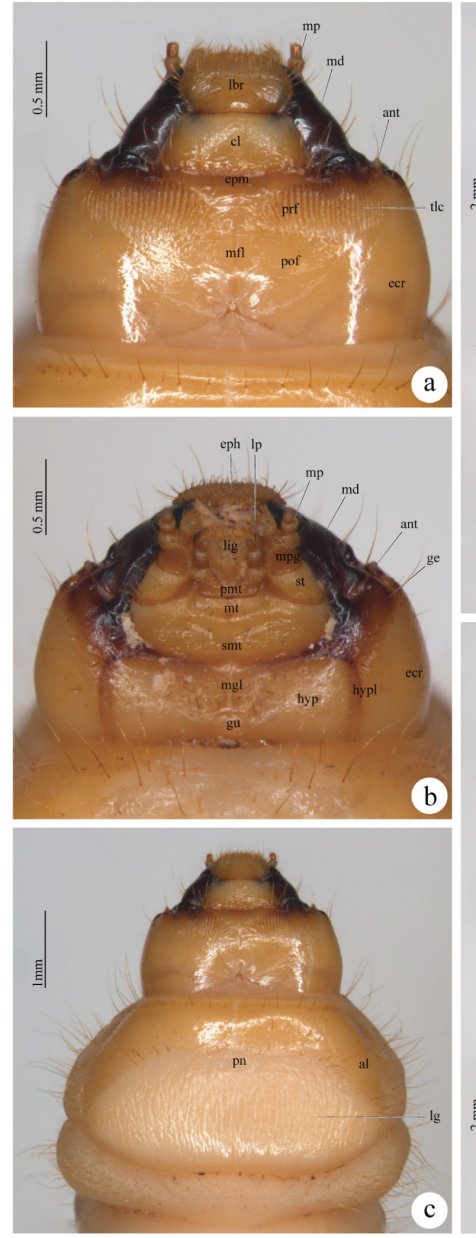

c
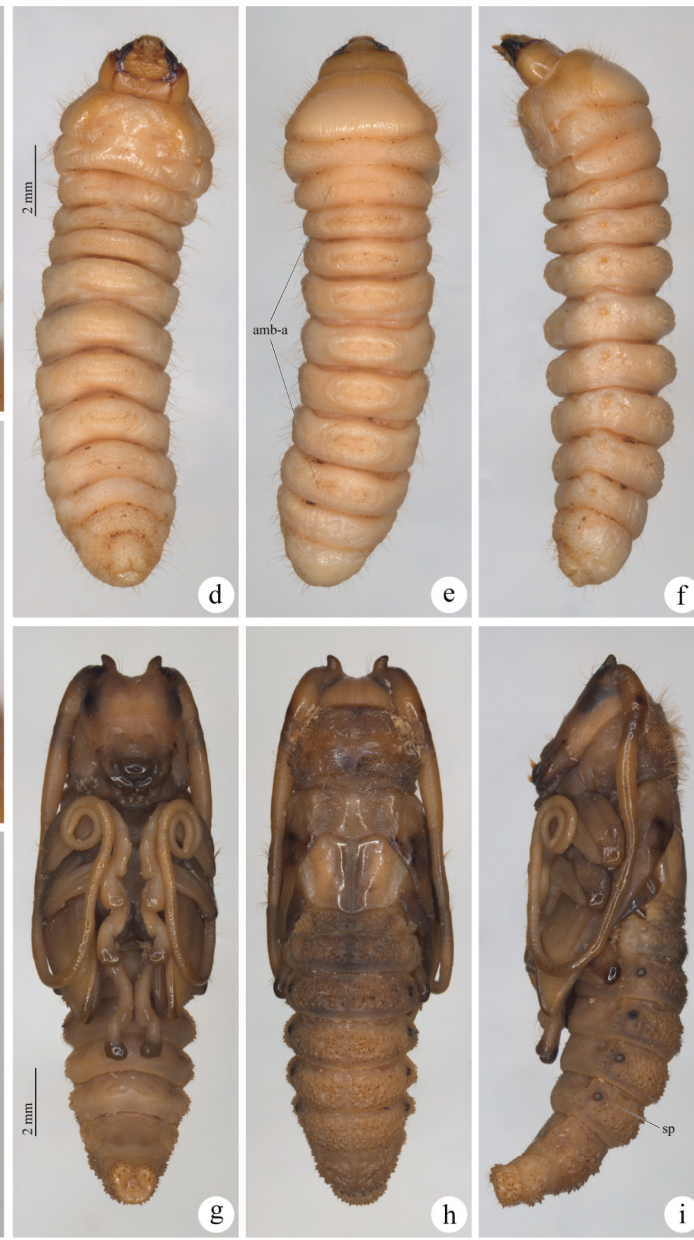

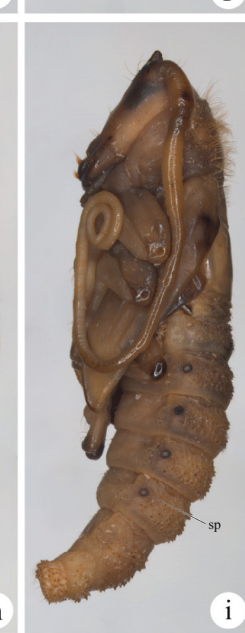

Figures 2. Habitus of larva and pupa of Psyllotoxus griseocinctus. a, head in dorsal view. $b$, head in ventral view. $c$, pronotum and head in dorsal view. d-f, larva in ventral, dorsal and lateral view. g-i, pupa in ventral, dorsal and lateral view. Abbreviations: al, alar lobe; $a m b-a$, ambulatory ampullae; ant, antenna; $c l$, clypeus; ecr, epicranium; eph, epipharynx; epm, epistomal margin; ge, gena; gu, gula; hyp, hypostoma; hypl, hypostomal line; lbr, labrum; lg, longitudinal grooves; lig, ligula; Ip, labial palp; $m d$, mandible; $m f l$, median frontal line; $\mathrm{mgl}$, median gular line; $m p$, maxillary palp; $m p g$, maxillary palpiger; $m t$, mentum; pmt, prementum; pn, pronotum; pof, postfrontal region; prf, prefrontal region; smt, submentum; sp, spiracles; st, stipes; tlc, transverse row of longitudinal carinae. glabrous area with several longitudinal grooves (lg); abdomen hairy and completely smooth; metathorax and abdominal segments I-VII with dorsal and ventral ambulatory ampullae $(a m b-a)$ as transverse rows of microtubercles.

The pupa (length $16.4-28 \mathrm{~mm}$ ) of $P$. griseocinctus can be identified by the following features (Figs. 2g-i): integument ferruginous to pale yellow; head glabrous, with sparse setae only on antennal tubercles, gena and clypeus; pronotum rugose, densely coated by long brown setae; antennal tubercles raised as a horn (only in males); abdomen dorsally with spine-like projections and short setae randomly distributed across the segments, ventrally glabrous; spiracles ( $s p$ ) present in abdominal segments I-VI.
Additionally, in order to improve the knowledge on taxonomy of $P$. griseocinctus and facilitate the identification of its immature stages through the use of molecular tools, we provide sequences of the DNA-barcode (cox1; $631 \mathrm{bp}$ ) of larva and adult specimens of $P$. griseocinctus. The sequences were deposited in GenBank under the following accession numbers: MT734797 (adult) and MT734798 (larva). These sequences represent the first molecular data available for the twig-girdling genus Psyllotoxus.

\section{Distribution of $P$. griseocinctus}

A total of 34 georeferenced records of $P$. griseocinctus were compiled for the modeling analysis, including records from all Brazilian 
states where the species is known to occur, according to Monné (2021) (see Table SI). These include new record data from 33 specimens deposited in the entomological collections of the DZUP and MZUSP. Most of the museum records were from the State of Paraná (10 new location records), followed by Santa Catarina (five new location records). Additional records of P. griseocinctus were also found for the Federal District (one new location record) and the states of Minas Gerais (one new location record), Rio de Janeiro (one new location record) and São Paulo (two new location records). All records obtained from museum specimens presented in Table SI are new municipality records and fill gaps in the distribution of $P$. griseocinctus.

The potential distribution of $P$. griseocinctus has a much broader continuous distribution than currently known, with the potential to occur in other Brazilian states lacking known records, including Espírito Santo and Mato Grosso do Sul, as well as in Argentina, Paraguay and Uruguay. According to the model, P. griseocinctus can be widely distributed across the Atlantic Forest and the Brazilian Savanna (Cerrado), and in the transition areas between these biomes. In addition to this large continuous area that stretches from the central region of Minas Gerais to the south of Uruguay, the model also predicts that $P$. griseocinctus has favorable environmental conditions to occur in isolated areas in Bahia, Goiás, Bolivia, Peru and Paraguay (Fig. 3).

\section{New host plant records}

Apart from confirming that P. griseocinctus can conclude its development in rose plants, herein we provide three new host plant records for this species found among the examined material deposited at DZUP: the cherry tree "Cerejeirado-Japão", Prunus cf. serrulata Lindl. (Rosaceae); the cambucá tree, Plinia edulis (Vell.) Sobral

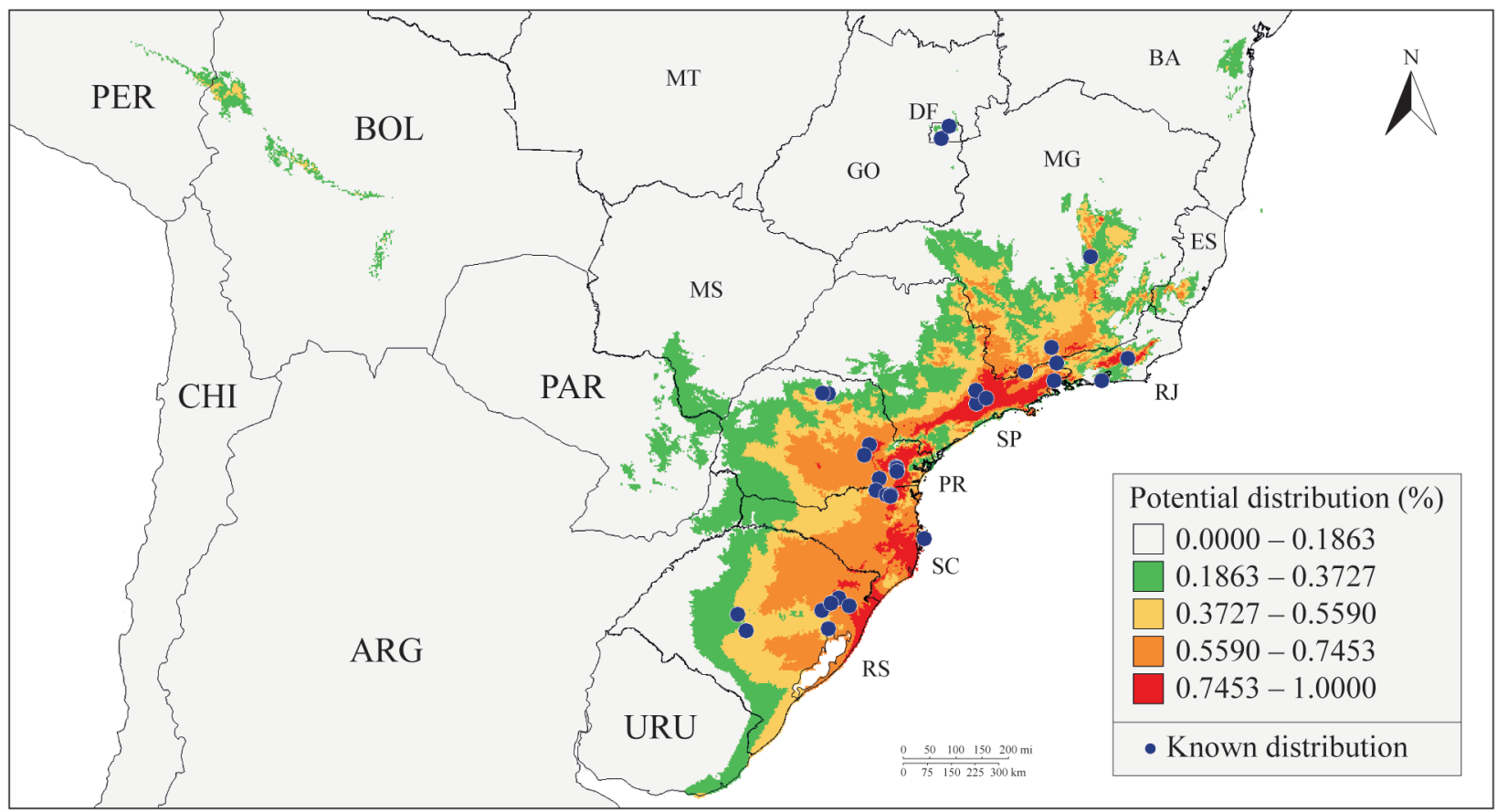

Figure 3. Potential and known distribution of Psyllotoxus griseocinctus in South America. Abbreviations: ARG, Argentina; BOL, Bolivia; CHI, Chile; PAR, Paraguay; PER, Peru; URU, Uruguay. Brazilian federative units: BA, Bahia; DF, Federal District; ES, Espírito Santo; GO, Goiás; MG, Minas Gerais; MS, Mato Grosso do Sul; MT, Mato Grosso; PR, Paraná; RJ, Rio de Janeiro; RS, Rio Grande do Sul; SC, Santa Catarina; SP, São Paulo. 
(Myrtaceae), a fruit tree native to the coastal zone of the Atlantic Forest; and the common walnut "Nogueira", Juglans regia L. (Juglandaceae), an exotic species economically significance in southern Brazil (see material examined in Table SI).

\section{DISCUSSION}

The only previous information relating $P$. griseocinctus with roses corresponds to a personal observation made by J.F. Zikán, cited by Zajciw (1972) and Monné (2021), with no further details. The present work provides details on the development of $P$. griseocinctus in Rosa sp., constituting the first formal record of this association. Our observations demonstrate that the complete development of P. griseocinctus in rose bushes, from the laying of eggs to the emergence of adults, lasts less than four months. The emergence of the adult in mid-January is within the range of the peak of abundance of the species found by Paro et al. (2012) in the Serra do Japi, in Minas Gerais, which goes from January to March. However, the life cycle of this beetle still needs to be further investigated, as its duration may vary depending on the species used as a host plant (Wang 2017). For example, Zajciw (1974a) stated that the duration of the larval stage and the time of emergence of adults are different among specimens that develop in pear trees ( $P$. communis) and peach trees ( $P$. persica).

The occurrence of $P$. griseocinctus causing damage in a rose plant in a garden suggests that this species is a potential pest in cultivated areas of rose, especially in monoculture growing crops. This beetle was classified by Zajciw (1974a) as the most dangerous pest of pear trees, Pyrus communis L. (Rosaceae), in Southern Brazil. In addition to pear trees, P. griseocinctus is recorded attacking a number of other species of Rosaceae, including peach trees (Silva et al. 1968, Zajciw 1974a), the European crab apple trees (Silva et al. 1968), roses and cherry trees (the last two documented in this work). However, the potential risk of $P$. griseocinctus to become a pest is not eminent only to Rosaceae, but also to Myrtaceae and Pinaceae species, such as eucalyptus and pine, which occupy a prominent position in the agroforestry sector in Brazil, and both serve as alternative host plants for $P$. griseocinctus (Silva et al. 1968, Paro et al. 2011).

Paro et al. (2011) investigated the host-plant range of twig-girdling beetles in a fragment of Atlantic Forest in southeastern Brazil and found that $P$. griseocinctus has the widest host-plant range among the Onciderini beetles, using eight different species from the families Lauraceae, Myrtaceae and Rosaceae for development, including both native (e.g., the guava trees, Psidium guajava and Psidium cattleianum) and exotic species (e.g., Eucalyptus sp. and the peach tree, Prunus persica). Thus, considering that $P$. griseocinctus is a generalist species with high colonization range (Paro et al. 2011, 2012), it is likely that in periods of increased population density, these beetles may seek alternative hosts, causing physical damage and consequent economic losses in commercial cultivations.

Psyllotoxus griseocinctus is currently known from Brazil in areas that comprise natural domains of Atlantic Forest and, in a smaller proportion, the Brazilian Savanna. In addition, the modeled map suggests that the species has the potential to occur (or to stablish) in disjoint areas with climatically suitable habitats in the northeast region of Brazil (State of Bahia), as well as in Bolivia and Peru. This distributional scenario is noteworthy and not unlikely to happen, as several harmful species of Onciderini (e.g., Oncideres saga (Dalman, 1823) and Oncideres ulcerosa (Germar, 1823)) 
and many other cerambycids typically found in the Atlantic Forest are also found in Bolivia, as documented in Monné (2021).

The potential distribution of $P$. griseocinctus estimated based on the bioclimatic variables suggests that the Atlantic Forest provide an ideal environment for the development of the species, in which the probability of occurrence is over $74 \%$ (see red areas in Fig. 3). However, the environmental conditions alone do not seem to act as a barrier for this species. The known records of the Federal District suggest that the species can successfully develop in drier environments, such as the Brazilian Savanna, as long as potential host plants are available.

The potential of $P$. griseocinctus to occupy areas relatively distant from its primary environment (in the Atlantic Forest) and its capacity to explore a wide variety of host plants raise warning signs about the establishment of the species as a pest of commercial crops in Brazil and other South American countries. Thus, the evidence compiled in this study, in combination with numerous other host plants records available in the literature (e. g., Silva et al. 1968, Zajciw 1974a, Paro et al. 2011, Wang 2017) should be taken into consideration for the monitoring and management of $P$. griseocinctus, because this beetle can compromise the production of roses in both gardens and cultivated areas, as well as to prevent the establishment of this species in roses or other commercially important crops in South America.

\section{Acknowledgments}

We are thankful to Francisco E. de L. Nascimento for providing information on the $P$. griseocinctus deposited in the Museu de Zoologia, Universidade de São Paulo (MZUSP). We also thank the anonymous reviewers for their suggestions to improve the manuscript. The Rede Paranaense de Coleções Biológicas - Taxonline (https://www.taxonline.bio.br) provided the equipment for morphological study and detailed photographs of the larva and pupa used in this manuscript. This work was partially supported by the Coordenação de Aperfeiçoamento de Pessoal de Nivel Superior (CAPES) [grant numbers 1754572, MS; Finance Code 001, PASV]; the Conselho Nacional de Desenvolvimento Científico e Tecnológico (CNPq) [grant numbers 159771/20188, TAS; 141974/2014-1, SL]; the Fundação Carlos Chagas Filho de Amparo à Pesquisa do Estado do Rio de Janeiro (FAPERJ) [grant number E-26/201.917/2020, DSS]; and the Programa de Pós-Graduação em Entomologia da Escola Superior de Agricultura Luiz de Queiroz, Universidade de São Paulo (ESALQ/USP).

\section{REFERENCES}

BEZARK LG. 2020. A photographic catalog of the Cerambycidae of the World. http://bezbycids.com/. Accessed 24 February 2020.

CARVALHO LM, ALMEIDA EFA, ALMEIDA K, LESSA MA, TAQUES TC, REIS SN, CURVELO ICS \& BARBOSA SS. 2013. Integrated production of roses: influence of soil management on the occurrence of pests and natural enemies. Acta Hortic 970: 361-366. https://doi.org/10.17660/ActaHortic.2013.970.44.

CHENG BCY, FU X-Q, GUO H, LI T, WU Z-Z, CHAN K \& YU Z-L. 2016. The genus Rosa and arthritis: Overview on pharmacological perspectives. Pharmacol Res 114: 219234. https://doi.org/10.1016/j.phrs.2016.10.029.

FICK SE \& HIJMANS RJ. 2017. WORLDCLIM 2: New 1-km spatial resolution climate surfaces for global land areas. Int J Climatol 37: 4302-4315. https://doi.org/10.1002/joc.5086.

FOLMER O, BLACK M, HOEH W, LUTZ R \& VRIJENHOEK R. 1994. DNA primers for amplification of mitochondrial cytochrome $C$ oxidase subunit I from diverse metazoan invertebrates. Mol Mar Biol Biotechnol 3(5): 294-299.

FOUGĖRE-DANEZAN M, JOLY S, BRUNEAU A, GAO X-F \& ZHANG L-B. 2015. Phylogeny and biogeography of wild roses with specific attention to polyploids. Ann Bot 115: 275-291. https://doi.org/10.1093/aob/mcu245.

HIJMANS R, GUARINO L \& MATHUR P. 2004. DIVA?GIS. Version 7.5. A geographic information system for the analysis of species distribution data. http://www.diva-gis.org. Accessed 14 March 2020

HURST C. 1941. Notes on the origin and evolution of our garden roses. J R Hortic Soc 66: 77-289.

JÚNIOR JCL, NAKATANI JK, NETO LCM, LIMA LACV, KALAKI RB \& CAMARGO RB. 2015. Mapeamento e Quantificação da Cadeia de Flores e Plantas Ornamentais do Brasil. São Paulo: OCESP, $122 \mathrm{p}$. 
JUNQUEIRA AH \& PEETZ MS. 2014. O setor produtivo de flores e plantas ornamentais do Brasil, no período de 2008 a 2013: atualizações, balanços e perspectivas. Rev Bras Hortic Ornam 20(2): 115-120. https://doi.org/10.14295/ rbho.v20i2.727.

LINK D, COSTA EC, ALVAREZ FA, CARVALHO S \& TARRAGÓ MFS. 1988. Serrador: levantamento das espécies, épocas de ocorrência e especificidade hospedeira (Coleoptera, Cerambycidae). 3. Gêneros Chitron, Psyllotoxus, Trachysomus, Lochmaeocles e plantas hospedeiras. In: Anais do VI Congreso Florestal Estadual, Rio Grande do Sul, p. 654-664.

MARINONI RC. 1969. Sôbre alguns Cerambycidae (Coleoptera) e suas plantas hospedeiras. Ciência e cultura 21(2): 470-471.

MARTIN M, PIOLA F, CHESSEL D, JAY M \& HEIZMANN P. 2001. The domestication process of the modern rose: genetic structure and allelic composition of the rose complex. Theor Appl Genet 102: 398-404. https://doi.org/10.1007/ s001220051660.

MARTINS MVM, VAZ APA \& MOSCA JL. 2009. Produção integrada de flores no Brasil. In: ZAMBOLIM L et al. (Eds) Produção integrada no Brasil: agropecuária sustentável, alimentos seguros. Brasília: MAPA/ACS, p. 491-496.

MONNÉ MA. 2021. Catalogue of the Cerambycidae (Coleoptera) of the Neotropical Region. Part II. Subfamily Laminae. https://cerambycids.com/. Accessed 29 July 2021.

NEARNS EH \& TAVAKILIAN GL. 2012. A new genus and five new species of Onciderini Thomson, 1860 (Coleoptera: Cerambycidae: Lamiinae) from South America, with notes on additional taxa. Insecta Mundi 266: 1-23. https://journals.flvc.org/mundi/article/view/ 0266.

OLIVEIRA LS \& COSTA EC. 2014. Insetos aneladores em povoamentos florestais. In: CANTARELLI EB \& COSTA EC (Eds) Entomologia Florestal Aplicada. Santa Maria: Editora UFSM, p. 57-70.

PARO CM, ARAB A \& VASCONCELLOS-NETO J. 2011. The host-plant range of twig-girdling beetles (Coleoptera: Cerambycidae: Lamiinae: Onciderini) of the Atlantic rainforest in southeastern Brazil. J Nat Hist 45: 1649-1665. https://doi.org/10.1080/00222933.2011.559601.

PARO CM, ARAB A \& VASCONCELLOS-NETO J. 2012. Population dynamics, seasonality and sex ratio of twig-girdling beetles (Coleoptera: Cerambycidae: Lamiinae: Onciderini) of an Atlantic rain forest in south-eastern Brazil. J Nat Hist 46(19-20): 1249-1261. http://dx.doi.org/10.1080/0022 2933.2012.654514.
PHILLIPS SJ, ANDERSON RP \& SCHAPIRE RE. 2006. Maximum entropy modeling of species geographic distributions. Ecol Model 190: 231-259. https://doi.org/10.1016/j. ecolmodel.2005.03.026.

SANTOS BB \& ROSADO-NETO GH. 1977. Ocorrência de Psyllotoxus griseocinctus Thomson, 1868 (Coleoptera, Cerambycidae) em carvalho (Quercus sp.) em Curitiba, Brasil. Dusenia 10(3): 199-200.

SANTOS GP \& MOURA VGP. 1979. Ocorrência de Psyllotoxus griseocinctus Thomson, 1868 (Coleoptera, Cerambycidae) em algumas procedências de eucalipto, no Distrito Federal. Silvicultura 14: 362-364.

SHARIFI S, JAVADI I \& CHEMSAK JA. 1970. Biology of the Rosaceae Branch Borer, Osphranteria coerulescens (Coleoptera: Cerambycidae). Ann Entomol Soc Am 63(6): 1515-1520.

SILVA AG, GONÇALVES CR, GALVÃO DM, GONÇALVES AJL, GOMES J, SILVA MN \& SIMONI L. 1968. Quarto catálogo dos insetos que vivem nas plantas do Brasil: seus parasitos e predadores. Parte 2, Tomo 1. Rio de Janeiro: Ministério da Agricultura, Laboratório Central de Patologia Vegetal, $622 \mathrm{p}$.

ŠMÍD J ET AL. 2017. Cutting the Gordian Knot? Phylogenetic and ecological diversification of the Mesalina brevirostris species complex (Squamata, Lacertidae). Zool Scr 46: 649-664. https://doi.org/10.1111/zSc.12254.

SOUZA DS, MARINONI L, MONNÉ ML \& GÓMEZ-ZURITA J. 2020. Molecular phylogenetic assessment of the tribal classification of Lamiinae (Coleoptera: Cerambycidae). Mol Phylogenetics Evol 145: 106736. https://doi. org/10.1016/j.ympev.2020.106736.

ŠVÁCHA P \& LAWRENCE JF. 2014. Cerambycidae Latreille, 1802. In: LESCHEN RAB \& BEUTEL RG (Eds) Handbook of Zoology, Arthropoda: Insecta; Coleoptera, Beetles, Volume 3: Morphology and systematics (Phytophaga). Berlin/ Boston: Walter de Gruyter, p. 77-177.

THE PLANT LIST. 2013. Version 1.1. http://www.theplantlist. org/. Accessed 25 February 2020.

WANG Q. 2017. Cerambycid Pests in Agricultural and Horticultural Crop. In: Cerambycidae of the World. biology and pest management. Boca Raton: CRC Press, p. 409-462.

WARREN DL, GLOR RE \& TURELLI M. 2010. ENMTOols: a toolbox for comparative studies of environmental niche models. Ecography 33: 607-611. https://doi. org/10.1111/j.16000587.2009.06142.x. 
ZAJCIW D. 1972. Contribuição para o estudo da fauna dos longicórneos do Parque Nacional do Itatiaia (Coleoptera, Cerambycidae). Brasil Florestal 3(12): 40-72.

ZAJCIW D. 1974a. Contribuição para o estudo da biologia de Psyllotoxus griseocinctus Thomson, 1868 (Coleoptera, Cerambycidae, Lamiinae). Brasil Florestal 5(18): 54-56.

ZAJCIW D. 1974b. Descriptions of larva and pupa of Psyllotoxus griseocinctus Thomson, 1868 (Coleoptera, Cerambycidae, Lamiinae). Rev Bras Biol 34: 339-396.

ZIKÁN JF \& ZIKÁN W. 1944. A inseto-fauna do Itatiaia e da Mantiqueira. Boletim do Ministerio de Agricultura 33(8): $1-50$.

\section{SUPPLEMENTARY MATERIAL}

\section{Table SI.}

\section{How to cite}

SOUZA DS, LAMPERT S, SEPÚLVEDA TA, SANZ-VEIGA PA \& SAVARIS M. 2021. Psyllotoxus griseocinctus Thomson, 1868 (Coleoptera: Cerambycidae): a potential pest of roses in Brazil revealed by its lifecycle and niche modeling. An Acad Bras Cienc 93: e20201076. DOI 10.1590/00013765202120201076.

Manuscript received on July 13, 2020;

accepted for publication on August 23, 2021

\section{DIEGO S. SOUZA ${ }^{1,2}$}

https://orcid.otg/0000-0003-3917-6559

\section{SILVANA LAMPERT ${ }^{3}$}

https://orcid.otg/0000-0002-7930-0289

\section{TATIANA A. SEPÚLVEDA ${ }^{2}$}

https://orcid.otg/0000-0002-6052-0775

PRISCILA A. SANZ-VEIGA ${ }^{4}$

https://orcid.otg/0000-0002-7096-2411

\section{MARCOANDRE SAVARIS ${ }^{3}$}

https://orcid.otg/0000-0002-9145-6059

${ }^{1}$ Museu Nacional, Universidade Federal do Rio de Janeiro, MNRJ, Departamento de Entomologia, Horto Botânico, Quinta da Boa Vista, São Cristóvão, 20940-040 Rio de Janeiro, RJ, Brazil

${ }^{2}$ Universidade Federal do Paraná/ UFPR, Departamento de Zoologia, Centro Politécnico, Caixa Postal 19020, Jardim das Américas, 81531-990 Curitiba, PR, Brazil

${ }^{3}$ Escola Superior de Agricultura "Luiz de Queiroz"

- ESALQ, Universidade de São Paulo/ USP,

Departamento de Entomologia e Acarologia, Av.

Pádua Dias 11, 13418-900 Piracicaba, SP, Brazil

${ }^{4}$ Universidade Estadual Paulista 'Júlio de Mesquita

Filho', Instituto de Biociências, Rua Prof. Dr. Antonio Celso

Wagner Zanin, 250, 18618-689 Botucatu, SP, Brazil

Correspondence to: Diego de Santana Souza

E-mail:dissouza.bio@gmail.com

\section{Author contributions}

DSS, MS, SL and PASV conceived and designed the research. MS and SL conduced the biological experiments. DSS and TAS conduced the molecular experiments and produced the map. All authors wrote and approved the manuscript.

(cc) BY 